Journal of Southeast Asian

\title{
Three Poems: qhuab ke; I Was Basking in the Lights of New York City, You Were Buried in Laos; In Pretense
}

Chelsey See Xiong

Little Laos on the Prairie, xiong.chelsey@gmail.com

Follow this and additional works at: https://docs.lib.purdue.edu/jsaaea

Part of the Poetry Commons

\section{Recommended Citation}

Xiong, Chelsey See (2019) "Three Poems: qhuab ke; I Was Basking in the Lights of New York City, You Were Buried in Laos; In Pretense," Journal of Southeast Asian American Education and Advancement. Vol. 14 : Iss. 1, Article 7.

DOI: $10.7771 / 2153-8999.1188$

Available at: https://docs.lib.purdue.edu/jsaaea/vol14/iss1/7

This document has been made available through Purdue e-Pubs, a service of the Purdue University Libraries. Please contact epubs@purdue.edu for additional information.

This is an Open Access journal. This means that it uses a funding model that does not charge readers or their institutions for access. Readers may freely read, download, copy, distribute, print, search, or link to the full texts of articles. This journal is covered under the CC BY-NC-ND license. 


\title{
ISAAEA Journal of Southeast Asian American Education and Advancement
}

Vol. 14 Iss. 1 (2019)

WWW.JSAAEA.org

\section{Creative and Literary Works}

\section{Three Poems}

\author{
Chelsey See Xiong \\ Little Laos on the Prairie
}

\section{qhuab ke}

when the song of our ancestors has been sung and the echoes of the qeej and nruas ceased to only whisper I will be home, but first on the back of a horse made of woods and my loved ones' cries, to a place I don't belong south of the Mekong border to gather the remnants of my birth

for 13 days I will not be close enough, as in dreams, we are separated by reality and in death, we are separated by time, space, and borders

so you will lay in your home in Laos and wait and I will wander and wonder how soon my loved ones will release me from south of the Mekong to be home with you

\footnotetext{
()

SORERIGHISRESERNEDReaders are free to copy, display, and distribute this article, as long as the work is attributed to the author(s) and the Journal of Southeast Asian American Education \& Advancement, it is distributed for non-commercial purposes only, and no alteration or transformation is made in the work. More details of this Creative Commons license are available at http://creativecommons.org/licenses/by-nc-nd/3.0/. All other uses must be approved by the author(s) or JSAAEA. Journal of Southeast Asian American Education \& Advancement, Vol. 14. Iss. 1. (2019) ISSN: 2153-8999
} 


\section{Was Basking in the Lights of New York City, You Were Buried in Laos}

If I tell you how

in the land of concrete and glass, your

skin could feel the chill of the winter creeping

through every inch of your body,

if you stay longer, you

could taste the atmosphere on your tongue

in the form of thin layers of ice,

would you stay with me?

You won't.

You seek the warmth of the sun, the heat of fire burning the air inside

your home,

the ashes of the incense,

an open sky where the moon and

the stars would lay side by side

above the sleeping rooster,

who would call you from your slumber

every morning.

So I carry your love with me

on the white thread my father tied

around my wrist,

on the copper snake bracelet my mother

bought me,

as they may be the bridge between the

home of my father in Xam Nua,

and my mother's in Xiangkhouang,

and the land that holds you

deeply cuddled within its fingers,

and I closed my eyes to dream

while standing,

wishing to see you reach out to me

from the crowd

but while I was basking in the lights of New York City, you were buried in Laos. 


\section{In Pretense}

why do you pretend like you didn't know when it died?

when it was dying, you heard it, you felt it,

for miles and miles

when it died,

you wrapped it in silk roses, laid it in a casket, and left it open

for the world to see

but it was only you, in the back looking at it, with the doors closed behind you so no one could get in you covered it with fresh flowers to hide the smell of death, to hide its decay, to pretend you didn't know

it was dead 


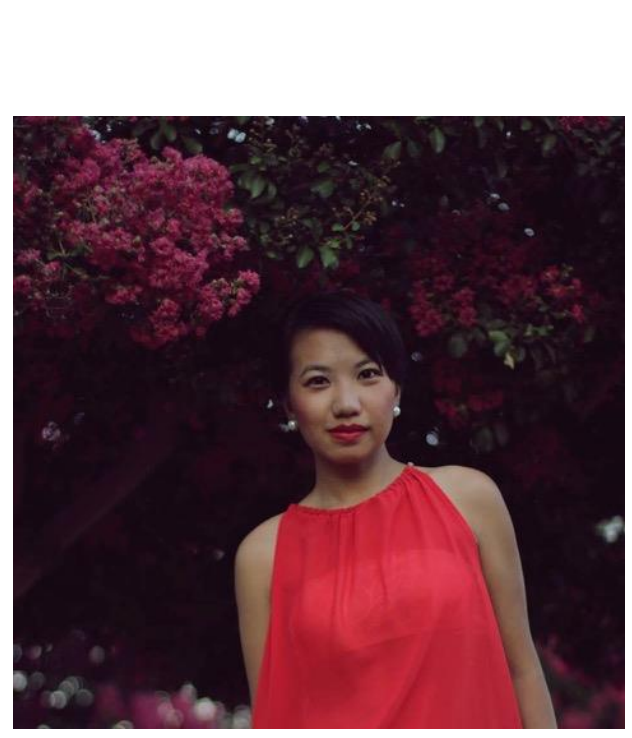

\section{About the Author}

Chelsey See Xiong identifies as Hmong American. She has published about Asian Americans in ethnic publications, including A-List Magazine, The Hmong Tribune, The kNOw Youth Media, Txhawb Magazine, and she started the online platforms and led the digital editorial work for Asian Pacific Review at her alma mater, California State University, Fresno. She worked on the Hmongstory 40 project, where she supported programs, communications, organized volunteers, researched, and wrote for the exhibition. She received the Critical Refugee Collective grant given by the University of California Critical Refugee Collective in 2017, for which she funded the printing of the zine series MAI. In 2018, she helped organize the Legacies of War LaoNow2018 Creative Feast in NYC. She also co-founded and is currently the co-editor of maivmai,_a digital Hmong American Literary Press. You can find her poetry in Files, Cockroaches and Poetry (2017), published by the Chicanx Writers and Artists Association at Fresno State. 


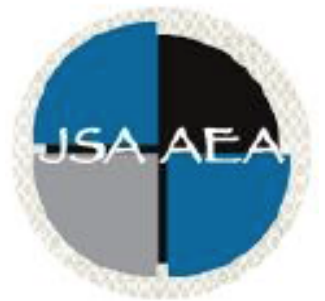

Vol.14 Iss.1 (2019)

\title{
Journal of Southeast Asian American Education and Advancement
}

\author{
www.JSAAEA.org
}

\section{Editor}

Dr. Wayne E. Wright

Purdue University

Associate Editors

Dr. Chhany Sak-Humphry

University of Hawaii at Manoa

Dr. Phitsamay Sychitkokhong Uy

University of Massachusetts, Lowell

\author{
Book Review Editor \\ Dr. Vichet Chhuon \\ University of Minnesota \\ Creative Works Editor \\ Bryan Thao Worra \\ Lao Assistance Center \\ Journal Manager \\ Fang Gao \\ Purdue University
}

\section{Editorial Review Board}

Dr. Steve Arounsack

California State University, Stanislaus

Dr. Sovicheth Boun

Salem State University

Dr. Virak Chan

Purdue University
Dr. Carl L. Bankston III

Tulane University

Dr. Phala Chea

Lowell Public Schools

Dr. George Chigas

University of Massachusetts, Lowell 


\author{
Dr. Loan Dao \\ University of Massachusetts Boston \\ Dr. Changming Duan \\ University of Missouri-Kansas City \\ Dr. Sothy Eng \\ Lehigh University \\ Dr. Vincent K. Her \\ University of Wisconsin, Eau Claire \\ Dr. Peter Nien-Chu Kiang \\ University of Massachusetts, Boston \\ Dr. Kevin K. Kumashiro \\ University of Illinois, Chicago \\ Dr. Ha Lam \\ Eastern Mennonite University \\ Dr. Jonathan H. X. Lee \\ San Francisco State University \\ Dr. Monirith Ly \\ Royal University of Phnom Penh \\ Dr. Bic Ngo \\ University of Minnesota \\ Dr. Leakhena Nou \\ California State University, Long Beach \\ Dr. Mark Pfeifer \\ SUNY Institute of Technology \\ Dr. Loan T. Phan \\ University of New Hampshire \\ Dr. Karen Quintiliani \\ California State University, Long Beach \\ Dr. Angela Reyes \\ Hunter College \\ The City University of New York \\ Dr. Fay Shin \\ California State University, Long Beach \\ Dr. Christine Su \\ College of San Mateo \\ Dr. Alisia Tran \\ Arizona State University \\ Dr. Khatharya Um \\ University of California, Berkeley \\ Dr. Kim Tran \\ University of California, Los Angeles, \\ Glendale Community College \\ Dr. Molly Wiebie \\ The University of Texas at Austin
}

Dr. Hien Duc Do

San Jose State University

Dr. Sophal Ear

Occidental College

Dr. Jeremy Hein

University of Wisconsin, Eau Claire

Dr. Nancy H. Hornberger

University of Pennsylvania

Dr. Peter Tan Keo

New York University

Dr. Yvonne Kwan

San Jose State University

Dr. Ravy Lao

California State University, Los Angeles

Dr. Stacey Lee

University of Wisconsin, Madison

Dr. Sue Needham

California State University, Dominguez Hills

Dr. Max Niedzwiecki

Daylight Consulting Group

Dr. Clara Park

California State University, Northridge

Dr. Giang Pham

University of Massachusetts Amherst

Dr. Malaphone Phommasa

University of Clifornia Santa Barbara

Dr. Kalyani Rai

University of Wisconsin-Milwaukee

Dr. Cathy J. Schlund-Vials

University of Connecticut, Storrs

Dr. Nancy J. Smith-Hefner

Boston University

Dr. Yer J. Thao

Portland State University

Dr. Monica M. Trieu

Purdue University

Dr. Silvy Un

Saint Paul Public Schools

Dr. Linda Trinh Vo

University of California, Irvine

Dr. Yang Sao Xiong

The University of Wisconsin-Madison

Dr. Zha Blong Xiong

University of Minnesota 


\section{Doctoral Student Editorial Review Board}

\author{
Diana Chandara \\ University of Minnesota \\ Bao Diep \\ University of Minnesota \\ Nielsen Hul \\ Cornell University \\ Vanessa Na \\ University of California, San Diego \\ Hoa Nha Nguyen \\ Boston College \\ Linda Marie Pheng \\ University of Wisconsin-Madison \\ Soua Xiong \\ San Diego State University \\ Melissa Vang \\ San Diego State University
}

\author{
Linh Dang \\ University of Rochester \\ Annie BichLoan Duong \\ San Joaquin County Office of Education \\ Dung Minh Mao \\ University of Minnesota \\ Thien-Huong Ninh \\ University of Southern California \\ Khoi Nguyen \\ George Mason University \\ Krissyvan Truong \\ Claremont Graduate University \\ Mai Vang \\ University of Massachusetts Boston \\ Thong Vang \\ University of Minnesota
}

